\title{
Explaining the Absence of a Japanese Central Intelligence Agency: Alliance Politics, Sectionalism, and Antimilitarism
}

\author{
Brad Williams
}

\begin{abstract}
I examine a relatively underexplored aspect of Japan's early postwar history and seek to explain why attempts to establish a Japanese-style central intelligence agency (JCIA) in the 1950s were unsuccessful. I evaluate three competing explanations drawn from the level of international politics, focusing on US power resources and influence as well as liberal and constructivist styles of analysis-alliance politics, sectionalism, and the norm of antimilitarism -in order to shed light on the historical origins of Japan's intelligence apparatus, which is relatively underdeveloped and underfunded compared to other middle powers. It highlights the primacy of domestic factors over structural causes in explaining the decision not to establish a JCIA. In particular, I argue that the JCIA proposal failed primarily because of attacks on important proponents that, while sometimes driven by seemingly rational organizational interests, were nevertheless legitimated by growing antimilitaristic sentiments shared by elites from the political center to the left of the ideological spectrum. The newly emerging norm of antimilitarism was predicated largely on a fear of constraints on recently acquired civil and political liberties. These fears, manifested most prominently in vocal Diet and media opposition, were compounded by the norm of secrecy-an important element of intelligence activities-which served to heighten further speculation about the malign intent of postwar Japan's reconstituted intelligence system. KeYwORDs: Antimilitarism, bureaucratic politics, ClA, democracy, intelligence, Japanese central intelligence agency, Japan-US alliance, Shigeru Yoshida, Taketora Ogata
\end{abstract}

THE RECENT WIKILEAKS SCANDAL HAS CAST THE SPOTLIGHT ON ISSUES relating to confidential information and intelligence that governments would naturally like to keep secret. Among the leaked materials is the startling revelation that the Japanese government has created a secret foreign intelligence unit under the authority of the Cabinet 
Intelligence and Research Office (Naikaku Kanbō Naikaku Jōhō Chōsashitsu or CIRO). Modeled on Western intelligence services such as the CIA, Britain's MI6, and Australia's Secret Intelligence Service, and with a primary focus on regional rivals China and North Korea, the new spy agency will allegedly prioritize the development of a "human intelligence collection capability" (HUMINT) (Dorling 2011).

While the idea of deploying Japanese agents abroad would represent a dramatic departure from established security doctrine and practice (Taigai Jōhō Kinō Kyōka ni kansuru Kondankai 2005), ${ }^{1}$ it is important to note that Japan, in fact, has long possessed several civilian and military agencies responsible for collecting, analyzing, and disseminating intelligence that are known to target foreign countries, relying heavily on image intelligence (IMINT), open-source intelligence (OSINT), and signals intelligence (SIGINT). Japan does, however, lack a comprehensive foreign intelligence-gathering organization like the CIA or MI6. Instead, Japan maintains a fairly decentralized intelligence system that centers on a "three pillar" institutional arrangement comprising the CIRO, the Public Security Intelligence Agency (Kōan Chōsachō or PSIA), and the Defense Intelligence Headquarters (Jōho Honbu or DIH) (Oros 2002). ${ }^{2}$ The CIRO is directly responsible to the cabinet. The PSIA and the DIH are under the formal authority of the Ministry of Justice and the Ministry of Defense, respectively, but are effectively self-contained in a relationship broadly analogous to the FBI and the US Department of Justice (Oros 2002, 5). Additional intelligence units are embedded in three civilian ministries: the Ministry of Foreign Affairs (Gaimushō or MOFA), the National Police Agency (Keisatsuchō or NPA), and the Ministry of Economy, Trade, and Industry (Keizai Sangyōshō or METI).

The CIRO, the predecessor of which was established in April 1952 , is often referred to as "Japan's CIA." This is a misleading analogy as the CIRO is a relatively small organization, lacks personnel and resources, and - the present claims notwithstanding - does not have the authority to deploy intelligence operatives abroad. A plausible explanation for the CIRO's truncated organizational scale and functions, indeed for the small size of the nation's overall intelligence "community," may well be that Japan's traditional low profile in international security affairs, facilitated by its alliance with the United States, meant it has been generally removed from the constant intrigues and maneuverings characteristic of the world of international espionage. As a result, Japan simply has not needed a comprehensive foreign intelligence organization. 
This perspective, however, obscures the fact that in the early 1950 s, the Japanese government, with cooperation from elements within the US intelligence establishment, gave serious consideration to the creation of such an organization. The proposal to establish a Japanese-style central intelligence agency (JCIA) prompted a widespread debate within the government and the mass media before it was ultimately abandoned in favor of a revision of existing structures. It was formulated at a tumultuous time in the nation's history. Japan was just emerging from occupation and was bitterly divided among a diverse array of actors across the political spectrum on the issue of national security. These actors ranged from neomilitarists to pacifists, who all had their own firmly held ideas about Japan's appropriate role, and requisite foreign economic and security policies, in the international community (Samuels 2007, chap. 1). The early postwar intelligence discourse in Japan should be seen within this volatile context but was often overshadowed by more high-profile security issues such as the US-Japan Security Treaty, the establishment of the National Police Reserve (NPR), and its evolution into the Ground Self-Defense Forces.

I shed light on this relatively underexplored aspect of Japan's early postwar history by seeking to explain why attempts to establish a JCIA - a relatively centralized agency possessing a foreign intelligence-gathering capability and a remit that also included politico-military matters - in the 1950 s were unsuccessful. In hindsight, it might not seem particularly puzzling that the Japanese government ultimately decided not to establish such an organization. Pursuing vastly different foreign policy objectives, one would not expect Japan to mimic the institutional capacity of its superpower patron, although, as discussed below, the United States did provide assistance in the form of potential models, such as the CIA, for the proposed Japanese organization. However, other middle powers and US allies such as Australia and (West) Germany did establish coherent organizations that possessed a declared foreign intelligence-gathering capability in the early Cold War period. Since this time, until reforms in the late 1990s, Japan also lagged behind other comparable powers such as France and Great Britain in the intelligence field in terms of funding and capabilities. Why did Japan not establish a more concentrated intelligence apparatus with a broader international mandate, despite domestic and US interest?

I evaluate three competing explanations drawn from the level of international politics, with a focus on US power resources and influence, 
as well as liberal and constructivist styles of analysis-alliance politics, sectionalism (bureaucratic politics), and the norm of antimilitarism - in order to shed light on the historical origins of Japan's relatively underdeveloped and underfunded intelligence apparatus. These three schools of thought, either separately or collectively, have been applied to postwar Japanese foreign and security policy and have also have been employed in analyses of Japan's intelligence system (Nakanishi 2010, 53-54). ${ }^{4}$ I emphasize the primacy of domestic factors over structural causes to explain this "historical nonevent." In particular, I argue that the JCIA proposal failed primarily because of attacks on important proponents that, while sometimes driven by seemingly rational organizational interests, were nevertheless legitimated by growing antimilitaristic sentiments shared by elites from the political center to the left of the ideological spectrum. The newly emerging norm of antimilitarism was predicated largely on a fear of constraints on recently acquired civil and political liberties. These fears, manifested most prominently in vocal Diet and media opposition, were compounded by the norm of secrecy-an important element of intelligence activities - which served to heighten further speculation about the malign intent of postwar Japan's reconstituted intelligence system.

\section{Alliance Politics}

Given the alliance with the United States and the presence of US military bases throughout the Japanese archipelago, one would expect Japan to hew closely to the US line on major security issues. Indeed, the primacy of the US factor has been a well-documented theme in the literature on postwar Japanese foreign policy. One should not be surprised that, by extension, the United States has loomed large over Japanese intelligence policy (Oros 2007). Consistent with an explanation that emphasizes US influence within the framework of alliance relations, one Japanese scholar sees Washington's discreet opposition as the most significant factor behind the absence of a JCIA (Nakanishi 2010, 54). It is certainly plausible that the United States was an important factor, especially at a time when Japan was economically weak, strategically vulnerable, and embedded in an asymmetric security relationship with its superpower patron. However, this fails to explain US cooperation with Japanese plans to establish a foreign intelligence agency, which, as outlined above, included providing models of the CIA. Moreover, while the United States dismantled Japan's 
wartime intelligence agencies as a component of its early occupationera demilitarizing reforms, there is little discernible evidence that indicates Washington sought to block the establishment of a major Japanese foreign intelligence-gathering organization in the early 1950s. On the contrary, it would seem that the United States played a positive, enabling role in Japanese plans to establish a JCIA. Thus, an explanation that emphasizes external factors, specifically in this instance a constraint in the form of pressure from a powerful ally with possibly diverging interests, lacks validity.

\section{Occupation-era Intelligence Cooperation}

In fact, bilateral intelligence cooperation can trace its origins to the initial phase of the occupation and was subsequently consolidated following the "reverse course" in the Supreme Commander of Allied Powers' (SCAP) policy as Japan was transformed from a US intelligence target to a platform in the struggle against communism in East Asia. The driving force behind the creation of this relationship was the German-born and staunchly anti-Communist head of SCAP's intelligence wing Major General Charles Willoughby. Under Willoughby's authority, G-2 established contact with an assortment of former Japanese military officers and nationalists whom it utilized in the battle to prevent the spread of Communist influence within Japan and the region. Under US stewardship, these individuals, some of whom operated under the cover of G-2's historical section (Kluckhohn 1952), ${ }^{5}$ established a loose intelligence network. Key figures in this network included Lieutenant-General Seizō Arisue, the chief of military intelligence for the general staff; Colonel Takushirō Hattori, former secretary to Prime Minister Tōjō and chief of the first section of the general staff's operations division who during the occupation headed a group responsible for formulating a plan to establish a future Japanese army and whom Willoughby tried unsuccessfully to install as the first commander of the NPR in 1950 (Mori 2008, 52); Lieutenant-General Torashirō Kawabe, deputy chief of staff for imperial $\mathrm{GHQ}^{6}$; Yoshio Kodama, an ultranationalist, underworld figure and wartime profiteer who was arguably the most famous and influential behind-the-scenes political power broker (kuromaku) in postwar Japan; Lieutenant-General Eiichi Tatsumi, Shigeru Yoshida's confidential military adviser (Yuasa 2010b) ${ }^{7}$; and Colonel Masanobu Tsuji, an officer with considerable operational experience in Southeast Asia who, after the war, became a best-selling author and politician before he mysteriously disappeared during travels in Asia. 
Many of these former Japanese military officers had criminal or suspected criminal pasts (Petersen 2006). As a former military attaché to Italy, Arisue played an important role in negotiations leading up to the 1940 Tripartite Pact with Germany and Italy, which led SCAP officials outside G-2 to consider indicting him as a Class A war criminal (Petersen 2006, 200). Hattori was "one of the principal planners of the successful Japanese army offensives of 1941-42" (Petersen 2006, 214). Kawabe was a former head of intelligence for the notorious Kwantung Army. While he was opposed to the Tripartite Pact, Tatsumi was aware he could be personally indicted as a war criminal following the torture of POWs by subordinates in the Eastern District Army (Yuasa 2010a). Tsuji was described as "a fanatical ideologue and pathologically brutal staff officer, [who] bore heavy responsibility for massacres in both Singapore and the Philippines" (Dower 2000, 511-512). Their specialized knowledge and skills made these individuals valuable assets in the eyes of their US handlers, and helped them avoid the fate of so many of their former colleagues in the military who were imprisoned or banned from public office (Petersen 2006, 211). ${ }^{8}$

The Japanese network was involved in an anti-Communist intelligence operation codenamed "Takematsu." Under operation "Matsu," operatives were responsible for collecting intelligence on the large number of agitators, saboteurs, and foreign agents from among Japanese POWs and civilians who were repatriated from Japan's former colonies. Members of "Take" ran covert operations across Asia, including in North Korea, India, Pakistan, mainland China, Taiwan, and the Soviet Far East. The public spotlight would be shone on a number of alleged crimes and incidents that arose from these clandestine missions during the so-called media and literary black boom of the 1960s (Johnson 1972, 351).

While the scale of activities was significant, the intelligence network achieved less-than-stellar results. The leading Japanese figures in this network were stridently anti-Communist, but many were primarily motivated by self-interest, chief of which was pecuniary gain. For its part, G-2 was happy to fund these operations and turn a blind eye to any improprieties committed along the way in the distant belief that they were furthering US strategic objectives. Many of the operatives were undoubtedly happy for the opportunity to earn a living in a devastated economy. A large number were not primarily interested in intelligence and saw cooperation with the United States as merely a means to bring about a right-wing nationalist resurgence 
(Petersen 2006, 202). While some of the leading figures in the network such as Arisue and Kawabe had a strong intelligence background, many of their underlings did not and exaggerated their abilities. The problems associated with the network were partly attributable to a general occupation practice in which each division within SCAP recruited its own experts and was given insufficient resources to monitor them (Petersen 2006, 202). These groups were also extremely fluid, uncoordinated, fragmented, and developed intense rivalries, which by the early 1950 s had facilitated their penetration by Chinese Communist agents (Dower 1969; Petersen 2006, 206-207). ${ }^{9}$

\section{External Factors:}

US Intelligence Cooperation but No JCIA

With the occupation slowly drawing to a close after the twin signings of the San Francisco Peace Treaty and the US-Japan Security Treaty in September 1951, the United States and Japan moved to establish the institutional groundwork for future bilateral intelligence cooperation. US and Japanese interests converged around the issue of establishing a Japanese intelligence organization. As Tetsuo Arima (2010b, 169) notes, an independent Japan would require an intelligence organization to complement the operations of the reconstituted military establishment. For the United States, the formal end of the occupation would mean the dismantling of SCAP and with it G-2. The subsequent cessation of US occupation funding would force the disparate bodies that comprised the Japanese intelligence network, especially the largest of the constituent groups-the Kawabe Agency-to cease operations. For the CIA, which began full-scale operations in Japan in the summer of 1948 (Haruna 2000, 245), the corollary was that it faced the prospect of not having a liaison partner in postoccupation Japan. ${ }^{10}$

In January 1952, Willoughby dispatched two members of G-2's Counter Intelligence Corps (CIC), its notorious leader, Lieutenant Colonel Jack Canon, ${ }^{11}$ and a close associate, Lieutenant Yon Chong, a Japanese-speaking intelligence officer from the South Korean Navy assigned to G-2 (Mercado 2002, 225), to Shigeru Yoshida's private residence in Ōiso to listen to the prime minister's thoughts on establishing a new intelligence organization in Japan. According to Chong's account of events, Yoshida then asked the two CIC agents to meet and discuss this plan in greater detail with Taketora Ogata, Yoshida's close political ally who had only recently been depurged and did not, at the time, hold an official government position. Canon and Chong 
obliged, and allegedly provided Ogata with a description of the structure and functions of various Western intelligence agencies including MI5, MI6, and the CIA (cited in Yuasa 2011). Canon is also believed to have suggested that the proposed Japanese organization be placed under prime ministerial authority, just as the CIA was under formal presidential jurisdiction, and that Yoshida's former secretary and head of the National Rural Police Force's Security Division, Jun Murai, would be an appropriate choice to head the new agency (Arima 2010a, 171). Canon's latter suggestion seems to have derived from Murai's work in gathering intelligence for G-2 (Hatakeyama 2007, 102; Mori 2008, 585). ${ }^{12}$ Shortly after, and in accordance with these discussions, the Cabinet Research Chamber (Naikaku Sōri Daijin Kanbō Chōsashitsu, CRC) was established in the Prime Minister's Office on April 9, 1952, with Murai as director, overseeing thirty staff (Jourdonnais 1963). ${ }^{13}$

The preceding discussion suggests the United States played a prominent role in the establishment of the CRC. The United States was influential in two main ways. First, in the early occupation period G-2 approached former Japanese military officers and nationalists to establish a network of anti-Communist intelligence groups. It provided these groups with resources but more importantly helped their members avoid prosecution when many had criminal or suspected criminal pasts. As will be discussed in the following section, some of these individuals were able to use this freedom to plan a new intelligence organization. Second, G-2 also cooperated by providing know-how on potential models for the proposed intelligence organization. US cooperation continued shortly after the establishment of the CRC when Ogata sought out, and received, assistance from the CIA as a model for his plans to establish a JCIA (Inoue 2008, 42). ${ }^{14}$ The Americans welcomed this idea-and subsequent relations of trust strengthened through this intelligence cooperation, coupled with expectations that Ogata would be able to unite the Japanese conservative camps, led to a CIA operation (code-named POCAPAN) to install Ogata as prime minister, which would ensure continued cooperation between the two countries (Mainichi Shimbun 2009; Waseda Daigaku Seiji Keizai Kenkyūjo 2009). ${ }^{15}$

Nevertheless, while the United States clearly cooperated in early Japanese efforts at intelligence institution building, there is little available evidence to suggest that overt opposition from Washington helped to veto the establishment of a JCIA (Haruna 2000, 525). ${ }^{16}$ This is not to say, of course, that US opinions were unimportant. Rather, 
the US factor was an indirect or background variable attributable to the bilateral alliance, which ensconced Japan within a protective strategic cocoon, and allowed Tokyo to focus its postwar energies on economic reconstruction and growth. ${ }^{17}$ In this case, the external factor is less valid in explaining the failed attempt to establish a JCIA than an explanation rooted in Japanese domestic politics.

At this point, it is instructive to examine briefly the case of Germany, since the US factor also loomed large in the establishment of that country's postwar intelligence architecture. Beginning in summer 1945, the United States engaged, developed, and financed a German intelligence organization called the Gehlen Agency/Organization led by former Wehrmacht officers and operatives, which provided Washington with intelligence on the Soviet Union and its Communist allies (Krieger 2009). ${ }^{18}$ In another parallel with the Japanese case, there were also collaborators in West Germany who saw cooperation with the United States as a means to achieve personal objectives, including remilitarization.

However, there is one important difference between the German and Japanese cases. In April 1956, under CIA auspices, a foreign intelligence agency, the Bundesnachrichtendienst (BND), was created from the Gehlen Organization and transferred to the government of the new West German state (Krieger 2009, 100-101; Schmidt-Eenboom 2001, 146). ${ }^{19}$ The BND also has a known foreign intelligence-gathering capability augmented by overseas stations (Schmidt-Eenboom 2001, 154). One might ask, then, why the United States would support the creation of a comprehensive foreign intelligence agency in Germany and not Japan, especially since both were important strategic allies.

Of course, this is not to say the alliance logic that tied the United States to its new security partners was identical. While Japan and West Germany fulfilled the role of bastions helping to contain the spread of communism within their respective regions, the nature of the threat to both countries differed. West Germany, embedded in the NATO multilateral alliance structure, faced a "real, if not imminent" threat of invasion from Soviet forces (Finnegan 2009, 4). The primary threat to West German security was therefore external. During the Cold War the Soviet Union evinced far greater concern for the security situation in Europe than in East Asia and lacked both the intention and capability to conduct large-scale military operations against Japan. Apart from periodic harassment activities on the edges of Japanese airspace and the shared maritime border, the Soviets were primarily interested in fomenting domestic unrest by Communist 
sympathizers in Japan in an ultimately failed bid to forestall closer ties between Tokyo and Washington. ${ }^{20}$ It has been noted how the G-2-sponsored Japanese intelligence network was also engaged in domestic anti-Communist operations. The internal leftist threat was a fundamental concern to Japanese authorities in the postoccupation years, as evidenced by the early establishment of the Public Security Intelligence Agency in July 1952 - an effectively self-contained body formally located within the Ministry of Justice, akin to the organizational relationship between the FBI and the US Department of Justice (Oros 2002, 5). The domestic Communist threat to law and order in Japan and its foreign origins were a key concern for Murai (1952) and other intelligence officials and would feature in plans to establish a JCIA.

Nevertheless, while the alliance logic differed, Japan was still situated in an unstable regional security environment and, along with its superpower patron, had a keen interest in acquiring further knowledge of Communist adversaries. Despite US cooperation, the Japanese government was unable to establish a JCIA in the 1950s. Domestic-level variables help explain why.

\section{Domestic Politics:}

\section{Yoshida's Activism and the Scourge of Sectionalism}

As mentioned above, there are several ministries and agencies engaged in intelligence activities in Japan. It should come as no surprise that the Japanese bureaucracy, like all other bureaucracies, does not always function as a monolith. In fact, jurisdictional disputes are extremely common to the extent that they are argued to be "the very life-blood of the Japanese bureaucracy" (Johnson 1977, 231). Some scholars attribute bureaucratic rivalries in Japan to unclear jurisdictional boundaries exacerbated by the complexity of many issues states face, the resolution of which frequently requires "interministerial consultations and coordination" (Calder 1988, 529; Koh 1989, 197). Relatively weak central decisionmaking authority on the part of the prime minister and cabinet (before reforms in 2001) made it difficult to overcome the pronounced "turf consciousness" within Japan's structure of "vertical administration" (tatewari gyōsei). As outlined below, unclear jurisdictional boundaries became an issue between the CRC and the MOFA following Ogata's proposal for a new intelligence body designed to track both foreign and domestic targets.

The decision to abandon the JCIA proposal in the early 1950s was not simply the result of the "pulling and hauling" and bargaining 
among different players in the governmental decisionmaking process, which the bureaucratic politics model highlights (see Allison 1971). In this instance, the proposal was seriously undermined by the loss of power and influence of key proponents due to attacks from political rivals motivated by personal and organizational interests. While the JCIA plan was a direct target of disaffected senior foreign ministry bureaucrats, it also suffered "collateral damage" from political struggles within the conservative political camp. In other words, bureaucratic and political infighting played a role in killing the JCIA proposal.

Bureaucratic politics in the intelligence field predate Japan's early postoccupation years. The well-known rivalry between the imperial army and navy extended also to intelligence, which was further compounded by tensions between operations and intelligence units (Kotani 2009). Interdepartmental rivalries were also prominent in occupied Japan, which were complex and multilayered, and affected relations within SCAP, especially between the more liberal-oriented government section under Colonel Courtney Whitney and Willoughby's antiCommunist G-2, as well as between the CIA and G-2 (Haruna 2000, 447, 458). ${ }^{21}$ As mentioned above, the G-2-sponsored intelligence network of former Japanese military officers and nationalists was also extremely fragmented and characterized by shifting loyalties among its members. This fluidity, in conjunction with the requisite secrecy surrounding intelligence agencies, probably accounts for scholars' varied descriptions of the network and its constituent groups (Arima 2010b, 45; Haruna 2000, 297; Hatakeyama 2007, 325; Mori 2008, 43). ${ }^{22}$ These rivalries extended beyond the US occupation, were embedded in Japan's bureaucratic structures, and negatively impacted plans for a JCIA.

\section{Yoshida's Activism}

The story of Japan's early postwar intelligence history is very much about the exercise of personal executive leadership to influence the institution-building process at an important historical juncture. Among domestic political actors in Japan, it was Prime Minister Yoshida who was a key driving force behind the proposal to establish a new intelligence organization. Yoshida believed that, along with skillful negotiating capabilities, an effective intelligence organization was essential for diplomacy (cited in Yuasa 2011). It was the Japanese prime minister who is believed to have initially approached Willoughby for advice in establishing a JCIA. Yoshida entrusted Tatsumi to make discreet preparations to establish the new intelligence agency and helped his confidential adviser avoid prosecution so he could carry 
out this role (Yuasa 2010a, 2010c). ${ }^{23}$ In a reflection of Yoshida's general enthusiasm for intelligence, he audaciously proposed sending businessmen into China to gather intelligence and engage in covert operations to create a "fifth column" that would sow divisions between the Chinese Communist Party government and the Chinese people. During the final months of his premiership in September 1954, he also floated the idea of creating a "minilateral high command" of Western powers based in Singapore under which overseas Chinese from Southeast Asia would infiltrate mainland China (Inoue 2008). ${ }^{24}$ Yoshida's activism in intelligence matters certainly stands in stark contrast with his lack of enthusiasm for large-scale remilitarization.

Based on their prewar experiences in government, Yoshida and Ogata were all too familiar with the scourge of sectionalism and hoped that Japan's new intelligence architecture would be able to overcome this incessant problem (Kurita 1996, 146-147). Events surrounding Ogata's proposal for a JCIA in November 1952 and Murai's involvement in the so-called black market dollar incident in September 1953 demonstrate clearly the obstacles that arose from sectionalism within organizations, both bureaucratic and political.

\section{The Ogata Proposal}

Shortly after his election to the House of Representatives, which was soon followed by his appointment to the influential position of chief cabinet secretary-highly unusual for a first-term Diet memberOgata announced a proposal for a new intelligence organization in November 1952. According to the Yomiuri Shimbun, Ogata's proposal comprised four elements:

1. The agency will intercept, collect, and analyze overseas radio and television communications, and so forth. The early aim is to intercept $300,000-400,000$ words of radio communications every day. The agency will also collect all (kotogotoku) domestic newspapers and communications and so forth.

2. Three hundred technicians and a small number of outstanding leaders will staff the agency. Since it is difficult to recruit staff exclusively from within the government, the agency will seek high-quality staff from private media organizations.

3. Since the agency will rationally utilize science and technology capabilities, it will not require a large budget. The agency will be under cabinet jurisdiction but because of fears this could be 
misinterpreted as a revival of the wartime Information Bureau $(J \bar{o} h \bar{o} k y o k u)$, it will be a public interest corporation $(k \bar{o} e k i$ hōjin).

4. The agency will collect and analyze secret information relating to the Japan Communist Party separately from the NPA and the PSIA (cited in Arima 2010b, 165-166; Meguro 1953, 26).

Ogata's proposal placed an emphasis on SIGINT and envisaged both foreign and domestic targets, thereby becoming a source of tension between the CRC and the MOFA. The proposal was notable in two further ways. First, as discussed in greater detail below, is the reference to Japan's wartime Information Bureau. Second, for all its controversy, the proposal did not make a direct reference to a declared intention to deploy operatives abroad. An acknowledged HUMINT capability was, in fact, one element of an ambitious threepoint plan for a JCIA that Murai had earlier proposed. This plan was believed to be the result of several discussions between Murai and Tatsumi and was one in which Ogata is thought to have placed high expectations (Inoue 2008, 46; Yuasa 2011) ${ }^{25}$ Another proposal that was also under government consideration at the time was one the former president of the Dōmei News Agency and an old acquaintance of Ogata, Inosuke Furuno, had formulated. Furuno's plan called for the establishment of an agency that would systematically collect and analyze foreign news broadcasts, as well as transmit information abroad (Inoue 2008, 45-46). ${ }^{26}$

The announcement of the Ogata and Furuno plans was immediately met by a wave of domestic criticism, which found expression in the print media in particular (Arima 2010a, 190), and forced the government to backtrack. Ogata's revised proposal called for cuts to the proposed budget and staff numbers, and, more importantly, only a minor expansion and upgrade of the existing CRC's capabilities rather than the creation of a JCIA (Arima 2010a, 196; Inoue 2008, 46). ${ }^{27}$ It has been suggested that the proposal for a new intelligence organization floundered due to a power struggle within the Liberal Party that featured former bureaucrats such as Naoto Ikeda and Eisaku Satō, who were concerned over Ogata's rising influence (Inoue 2008, 46). Elements within the MOFA were also especially concerned by these developments and would allegedly be at the center of a Machiavellian plot to assert dominance over the intelligence institution-building process less than ten months later. 
The Murai "Black Market Dollar Incident"

In September 1953, Murai left Tokyo's Haneda Airport for an ostensibly private overseas visit. This was a ruse: the CRC head was, in fact, traveling to Washington for a clandestine meeting with CIA officials, including director Allen Dulles. Despite the cover of a private visit, Murai was accompanied by a CIA agent and had been issued with an official government passport. This choice of passport would partly prove to be his undoing. After successful talks with Dulles, Murai departed for London where he was embroiled in an unexpected scandal. Upon leaving the aircraft, Murai was detained and forced to undergo a body search, which turned up approximately $\$ 3,000$ in undeclared currency. After his money was confiscated, Murai was then pressed by British authorities on why he was using a government passport for a private visit. Murai's detainment and questioning caused a scandal in Japan and forced Yoshida to relieve the beleaguered CRC director of his post (Haruna 2000, 526-527). ${ }^{28}$ Following an interim replacement, Kōzō Kimura was appointed to the post of CRC director in January 1954. Kimura's appointment marked the cementing of a tradition, which began with Murai, of filling the CRC (and later CIRO) directorship from within the police ranks. In a possible concession to bureaucratic sensitivities, a MOFA official is usually appointed to the deputy directorship (Kitaoka 2005).

Just how Murai came to be caught up in this scandal is a source of great controversy. Mikio Haruna $(2000,528)$ claims that the British government was alarmed that it had not been informed beforehand of Murai's visit, which led to the rigorous immigration and customs inspection. In a sensational account, Tetsuo Arima (2010b, 170-172) raises the possibility that it was a Japanese foreign ministry official, Nobunori Higure, seconded to the CRC in a practice reminiscent of the "colonization" of the former Japan Defense Agency by personnel from other powerful ministries designed to limit a more forceful articulation of security policy (see Katzenstein and Okawara 1993), and later revealed to be a Soviet agent, who allegedly leaked details of Murai's overseas visit to MI6. ${ }^{29}$

The secondment of Higure, an expert on the Soviet Union, seems to have also been partly the product of political machinations by senior officials within the MOFA, which was embroiled in a bitter interagency dispute with remnants of the prewar Home Ministry (Naimu$s h \bar{o}$, which was responsible for the police), over control of Japan's nascent foreign intelligence architecture. It was influential foreign ministry official Akira Sono who dispatched Higure to the CRC, 
quite possibly to monitor Murai. Sono, who is alleged to have had links with the Arisue Agency (Arima 2010b, 78), was at the forefront of the MOFA's own proposal for an intelligence agency. Along with Vice Minister Katsuzō Okumura, he felt that the CRC was infringing on the MOFA's jurisdiction and should therefore concentrate its efforts on domestic affairs (Waseda Daigaku Seiji Keizai Kenkyūjo 2009; Yuasa 2011). ${ }^{30}$ Following this advice might have eased the MOFA's concerns but would have caused similar problems between the CRC and the recently established PSIA. Both Chong and Tatsumi suggest elements within the MOFA were involved in the Murai scandal without elaborating further (cited in Ōmori 2005, 37; Yuasa 2011). ${ }^{31}$ Given his robust views about the functions of a new Japanese intelligence agency, turf-conscious elements within the MOFA probably stood to gain from Murai's fall from grace. Efforts within Japan to establish such an organization certainly lost momentum as a result of the Murai scandal and received a further, perhaps more telling, blow after Yoshida's downfall in 1954 and then Ogata's sudden death in early 1956. Together, the removal from power of these three advocates of a more robust intelligence system contributed to the failure of the JCIA plan.

At the same time, an additional obstacle to the JCIA proposal emerged from within the Diet and mass media. By this early stage in postwar Japan, new ideas about the appropriate role of the military in state and society and the utility of force in international affairs had emerged and begun to take root. These ideational variables also had implications for postwar Japan's intelligence system.

\section{Antimilitarism and Intelligence}

In contrast with rationalist theories that emphasize material factors, constructivist approaches draw attention to the role of ideational variables such as norms, ideas, beliefs, and strategic culture in identity formation and the subsequent impact it has on state behavior in the international system. Scholars working within a constructivist framework such as Thomas Berger $(1993,1998)$ and Peter Katzenstein (1996) highlight the role of a culture or norm of antimilitarism, which has negatively shaped Japanese views on the military establishment and the development and foreign deployment of military power.

The norm of antimilitarism has naturally been mostly applied to explain the military's constrained role in Japan's minimalist postwar security policy. Despite its centrality to security policy formulation, 
very little has been said about the impact of antimilitarism on Japanese intelligence. ${ }^{32}$ As the discussion below highlights, antimilitarism helped shape the thinking of important political actors, which served to frustrate plans for a JCIA.

\section{Two Sides of the Same Coin:}

\section{Military Adventurism and a Police State}

As noted above, an important element of this norm of antimilitarism is the distrust in Japan of the military establishment. As Berger (1993, 120) notes, these suspicions have their origins "in collective Japanese memories of the militarist takeover in the 1930s and the subsequent disastrous decision to go to war with America." Japan's prewar intelligence organizations, which were ostensibly tasked with the responsibility of collecting, analyzing, and disseminating information, might not be readily associated with the military establishment and the negativity that surrounded it. However, for older generations of Japanese, these organizations did not just innocently participate in intelligencegathering activities.

Japan's prewar and wartime intelligence agencies operated both at home and abroad. While the military ran amok and committed atrocities in foreign areas under its control, members of ultranationalist secret societies such as the Dark Ocean Society (Genyōsha) and the Black Dragon Society (Kokuryūkai) and military intelligence agents, such as those from the famed Nakano School, not only gathered information but also engaged in a range of subversive activities that included assassination, spreading propaganda (disinformation), sabotage, and raiding enemy targets. With defeat imminent, Nakano agents were also involved in organizing local guerrillas for the final defense of Japan (Mercado 2002). Japanese intelligence operatives working in the so-called special service agencies (tokumu kikan) thus played an important supplementary role in Japan's war effort by "preced[ing], expand[ing] upon and consolidat[ing] the military occupations in Asia and the Pacific" (Jourdonnais 1963).

The domestic equivalents of the tokumu kikan in the security agencies such as the Special Higher Police (tokkō), or "thought police," and the military police (kempeitai), which performed functions more akin to the German gestapo and the Soviet NKVD rather than merely serving as a law enforcement branch of the army, were instruments of repression designed to perpetuate military rule at home (Jourdonnais 1963). In many ways, the foreign intelligence and domestic security agencies, which represented unconstrained overseas 
military adventurism and a domestic police state, respectively, were two sides of the same militaristic coin. Japan's devastating wartime defeat affected how Japanese elites and the public viewed security issues, which also came "to include [both] foreign intelligence gathering and domestic information controls" (Hansen 1996, 34).

The ensuing norm of antimilitarism negatively shaped Japanese perceptions of intelligence in two ways. First, given its supplementary role in Japan's military conquests, foreign intelligence gathering, especially HUMINT, naturally came to be closely associated with the notion of using force as a means to pursue national interests and, therefore, clashed with emerging pacifist ideals. The clandestine nature of the special service agencies' subversive operations also contributed to a broader perception of intelligence as "dark, shady and unclean" (Nakanishi 2010, 42; Tsukamoto 2008, 210), serving further to encourage Japanese suspicions (gishin anki). Second, domestic information controls - the tools of a police state-conflicted with the domestic political norm of antitraditionalism and its emphasis on promoting a mature, liberal democracy (Izumikawa 2010). ${ }^{33}$

\section{Diet and Media Opposition}

It was the perceived threat Japan's developing intelligence architecture posed to the nation's nascent democracy, in particular, that caused alarm in the Diet, most notably from those on the left and the media. The views of the Right Socialist Party's Suejirō Yoshikawa summed up Diet opposition to Ogata's proposal in late 1952. Yoshikawa and others on the left feared that through alleged links with NHK and other Japanese news agencies, the establishment of a new intelligence body would result in suppression and control of speech (genron no appaku, genron no tōsei) and a revival of the secret police, and could ultimately pave the way for constitutional revision and remilitarization (Sangiin 1952). The left's concerns over proposals that rekindled images of prewar political repression and that also represented an assault on postwar democratic reforms were understandable given it was a target of the militarist regime. The print media, especially the Yomiuri Shimbun and Mainichi Shimbun, devoted large sections to Diet proceedings and provided their own stinging headlines and analyses (cited in Arima 2010a, 190). The furor surrounding the proposal even forced Yoshida to tread delicately during Diet deliberations (Shūgiin 1952).

Ogata himself came under personal scrutiny, primarily due to his position as head of the wartime Information Bureau from mid-1944 
to April 1945 in the cabinet of Kuniaki Koiso. The Information Bureau was established in December 1940 to strengthen propaganda and thought control and to shape domestic opinion in support of the war effort. Ogata had previously forged a successful career in journalism, rising to become the chief editor and vice president of the Asahi Shimbun before leaving the newspaper in 1944 after a fallingout with the ownership. As head of the Information Bureau, Ogata adopted a policy of "easing restrictions on speech" (genron no chōtatsu), which sought to establish a less domineering relationship with the media and public opinion than that during the repressive Tōjo premiership (October 1941-July 1944). Ogata intended for this policy to expose the Japanese people to the truth as much as possible regarding battlefield results, thereby personalizing the war for them. He also believed that increasing the flow of reliable information to the media would strengthen relations between it and the bureau $(\mathrm{Ku}-$ rita 1996, 124).

However, it is important not to exaggerate the liberal nature of the Information Bureau under Ogata's stewardship. Ogata's policy also expected that the Japanese media would, when necessary, act appropriately as instruments of the military regime. Moreover, Ogata also believed that the Information Bureau had an important role to play in ideological warfare, complementary to the military's responsibilities on the battlefield (Kurita 1996, 131, 132, 139).

As Ogata's relationship with the media and public opinion as leader of the Information Bureau suggests, his wartime record was mixed: on the one hand, he was not an enthusiastic advocate of the war in China; in fact, toward the end of the war Ogata strove to achieve peace with Chiang Kai-shek. On the other hand, he was committed to Konoe's New Order; during his time at the Asahi Shimbun he promoted cooperation with the military, was a leading figure in the Imperial Rule Assistance Association (Taisei Yokusankai), was wartime minister, and also had a close relationship with prominent ultranationalists such as Mitsuru Tōyama and Seigō Nakano (Kurita 1996, 172). Ogata did enough during the war to be purged from politics in 1946 and to be a person of concern for those on the left opposed to plans to establish a JCIA. While the socialists had split over the San Francisco Peace Treaty in October 1951, as an aggregate, and with the help of the media, they were able to exercise sufficient veto power to complicate efforts to establish a JCIA. ${ }^{34}$

Diet members have regularly expressed unease over the CRC and its institutional successor, the CIRO, since the unsuccessful attempt to 
create a JCIA in the early 1950s. These concerns have been compounded by the necessarily secretive nature of intelligence, as well as inadequate oversight mechanisms (Williams 2010). Issues of concern in the Diet have included the CIRO's rising budget, relationships with extragovernmental organizations (gaikaku dantai) and the CIA, which is alleged to facilitate espionage (Shūgiin 1967), ${ }^{35}$ purported links with the Ground Self-defense Forces' intelligence arm, Nibetsu, which is somehow proof of its support of militarism (Sangiin 1977), ${ }^{36}$ and its supposed contribution to Japan's development as a "thought control state" (shisō kokka) by engaging in psychological warfare and the manipulation of public opinion (Sangiin 1986; Shügiin 1958, 1986). While few could seriously make the claim that, with the CIRO's assistance, postwar Japan was inexorably regressing toward its totalitarian past, those on the left did have wide-ranging, deep-rooted, and sometimes legitimate, concerns over attempts to reestablish and strengthen the nation's intelligence agencies. Mirroring the traditional Japanese distrust of the military, wartime legacies would also be difficult to overcome for advocates in a nation that suffered from an "intelligence agency allergy" (Sangiin 1983). ${ }^{37}$ This intelligence phobia has made it difficult for Japan to wear the cloak and wield the dagger.

\section{Conclusion}

In the early 1950 s, the Japanese government undertook serious efforts to establish a JCIA. These early attempts at intelligence institution building came at a volatile time when Japan was making its first cautious steps to reestablish its armed forces. Just as the United States prodded Japan in the direction of remilitarization, it also actively encouraged Tokyo to establish a new foreign intelligence agency. However, unlike the case of rearmament, the Japanese government's efforts to create a JCIA were not merely a passive response to US pressure (beiatsu). Individual political actors in Japan, most notably Prime Minister Yoshida and his chief cabinet secretary Taketora Ogata, played important roles in advancing this process. Yoshida's intelligence activism stands in stark contrast with his reluctance to accommodate US demands for substantial rearmament. Indeed, in some ways, Yoshida was out in front of the United States when it came to formulating proposals to employ intelligence aggressively in the struggle to contain the spread of communism in East Asia. Yoshida believed that large-scale remilitarization entailed the 
risks of overburdening Japan's fragile economy and inciting protest both within Japan and the countries of Asia (Dower 2000, 548). It is possible to surmise that Yoshida felt the establishment of a JCIA, as an important supplement to diplomacy, would not contribute to these problems. However, his aggressive proposal for intelligence operations against China did not risk Japanese entrapment in a US-led conflicta fear that arose from remilitarization-but the inverse: an unprecedented occurrence in which the United States would be potentially embroiled in an aggressive Japanese-conceived foreign operation. ${ }^{38}$

While the United States did not lend support to Yoshida's "counter infiltration" proposal targeting China, effectively killing it off, there is no evidence to suggest that Washington's opposition was decisive in the Japanese government's abandonment of plans to create a JCIA in the early 1950s. Instead, I have argued that domestic factors, sectionalism, and especially antimilitarism, hold more explanatory value.

Jurisdictional disputes between the MOFA and the police and, to a lesser extent, rivalries within the Liberal Party served to thwart efforts to establish a JCIA. Senior officials within the MOFA, who thought a police-led foreign intelligence organization would encroach upon their turf, are believed to have plotted to bring about the downfall of a key proponent of a JCIA, Jun Murai. Factionalism within the Liberal Party, of which the main cleavage was between the former bureaucrats and the long-term party politicians who had been depurged, along with his own high-handedness, contributed to Yoshida's downfall in late 1954. Ogata also had rivals within the party who were wary of his rising power and his plan for a JCIA is believed to have also stalled as a result of this struggle. His sudden death in early 1956 removed any hopes to resuscitate the proposal. If plans to establish a JCIA were the product of ambitious political actors working closely together, it should come as no surprise that its eventual abandonment is closely tied to the declining political fortunes of these individuals.

Bureaucratic and party rivalries, however, were not the only politics to affect plans for a JCIA. By the early 1950s, new ideas had emerged in Japan about the military and the use of force in international affairs, which represented a renunciation of previous martial values. A culture of antimilitarism took root in Japan that resulted in a profound distrust of the military establishment. Antimilitarism led Japanese citizens to perceive intelligence negatively by linking it with the notion of using force as a means to pursue national interests, which clashed with emerging pacifist ideals, manifested most notably 
in the so-called peace constitution. More importantly, attempts to establish a new intelligence system rekindled images of prewar repression and a retreat from democratic reforms, especially freedom of speech and thought. As a result, the left and the media, as targets of the Japanese police state, vehemently opposed plans to establish a JCIA in the early 1950 s and forced its proponents to abandon this endeavor. An emerging culture of antimilitarism therefore informed the thinking of certain political actors, which served as a broader constraint during this period of intelligence institution building.

Fast-forwarding to the present, Japan's intelligence capabilities are currently being upgraded and improved to meet rising regional threats. The most prominent example of this improvement is the nation's spy satellite program. This trend contrasts with historical evidence that highlights the constraints imposed by the norm of antimilitarism on Japanese intelligence. Reforms to Japanese intelligence can be attributed to eroding but residual antimilitarism and are reflective of gradual progress "toward more realist-oriented security policies" (Oros 2007, 35; Pekkanen and Kallender-Umezu 2010). This more robust position in international security affairs has been aided by the demise of the parliamentary left, which, in conjunction with pragmatists in the LDP, was able to keep a check on attempts to craft a more muscular security policy during the Cold War (Boyd and Samuels 2005). The suggestion outlined at the beginning of this essay that Japan is considering the development of HUMINT capabilities should be seen within this altered domestic and international milieu.

Importantly, the enhancement of Japan's intelligence capabilities has implications for democratic accountability. The CIRO, as noted above, has been a periodic concern for Japan's Diet, elements of which, rightly or wrongly, see the organization in the menacing context of militarism and democratic retreat. A number of scandals such as alleged Chinese honeytrap incidents (2004 and 2006), and intelligence leaks that extended beyond the CIRO, facilitated by inadequate oversight mechanisms - parliamentary, judicial, and bureaucratichave undoubtedly stoked fears in the Diet and elsewhere. As the nation's intelligence capabilities are improved, Japan's inadequate oversight mechanisms will need to be improved significantly in order to ensure "the balance between national requirements and the demands of democracy in Japan" does not tilt too heavily in favor of the former (Williams 2010,162). Keeping an eye on the watchmen in the intelligence services will help to keep old fears from becoming a new reality. 
Brad Williams teaches in the Department of Asian and International Studies, City University of Hong Kong. His research interests include Japanese domestic politics and foreign policy and international relations in East Asia. He is the author of Resolving the Russo-Japanese Territorial Dispute: Hokkaido-Sakhalin Relations (2007) and the coeditor of Japan and Asia-Pacific Security (2006) and Japan in Decline: Fact or Fiction? (2011). He has also published in several internationally refereed journals.

\section{Notes}

The author is grateful to Stephan Haggard, Lam Peng Er, Saadia Pekkanen, and the anonymous reviewers for extremely helpful comments on earlier versions of this article.

1. While the leaked document claims that the LDP government under Yasuo Fukuda and his successor, Tarō Asō, took this decision, Japanese administrations have considered the proposal for some time.

2. Strictly speaking, this term originally referred to CIRO, PSIA, and the Ground Self-defense Force Staff Office Annex. The latter was reorganized into the DIH's Signals Division (Anonymous 1982).

3. As a result of traditional bureaucratic politics, manifested in often petty jurisdictional squabbling, intelligence activities are poorly integrated, leading some observers to question the actual existence of an intelligence "community" in Japan (Handa 1999; Kuroi 2007).

4. Terumasa Nakanishi $(2010,54)$ refers to these three factors as the "trinity" (sanmi ittai) but does not offer a substantial explanation of their impact on Japan's postwar intelligence system.

5. Here they also worked on Willoughby's pet project, described as a three-volume "glorification of the war in the Pacific as conducted by MacArthur" (Kluckhohn 1952).

6. Kawabe was part of the mission to Manila to confer with MacArthur on the details of the coming occupation where, after an awkward beginning, the German-speaking Kawabe allegedly struck up something of a rapport with US officers, especially Willoughby.

7. Tatsumi had known Yoshida since he served as defense attaché during Yoshida's ambassadorship to London between 1936 and 1938. Despite his own personal misgivings about the merits of an agreement that would inevitably lead to conflict with the United States and the United Kingdom, Tatsumi had been charged with the ultimately unsuccessful task of trying to convince Yoshida of the merits of the Anti-Comintern Pact.

8. Kodama was, in fact, imprisoned but was released in 1948 after which he established cooperative relations with the CIA. While initially promising, the relationship turned out to be relatively short-lived after the CIA cut ties with Kodama in the early 1950s because of his unflattering personal qualities, which made him an intelligence liability (Petersen 2006, 211).

9. According to John Dower (1969), the Soviets were, to their chagrin, also aware that former Japanese officers were working within the occupation 
bureaucracy. As a result, these groups and their activities were probably not so secret.

10. Arima (2010b) claims that the United States was more than eager to cooperate; it actually pressured the Japanese to establish an intelligence organization.

11. Canon earned a reputation for the often-brazen and crude manner in which he conducted investigations.

12. According to Hatakeyama $(2007,102)$, Murai was a frequent visitor to the former Iwasaki Family House where Canon was based and hosted social gatherings.

13. In a declassified 1963 CIA report, this organization is translated as the Cabinet Research Chamber (Jourdonnais 1963).

14. Ogata was also apparently interested in acquiring information about the US National Security Council (Arima 2010a).

15. Ogata's sudden death in January 1956 forced the CIA to shift its attention to cultivating relations with Okinori Kaya and Nobusuke Kishi.

16. Mikio Haruna $(2000,525)$ claims that the CIA did convey the view that the CRC should collect and analyze information and not engage in covert operations.

17. It could be also argued that Japan's mercantilist foreign policy and low profile in international security affairs obviated the necessity of establishing a politico-military-oriented JCIA. In light of Japan's postwar economic-centric foreign policy objectives, some have noted that the Japan External Trade Organization (JETRO), a semipublic entity under METI's jurisdiction, which collects and analyzes foreign economic data, has been described as a "de facto intelligence agency" (Oros 2002, 14).

18. The organization was named after the Wehrmacht major general and first president of the BND, Reinhard Gehlen.

19. This is not to say that German intelligence operations are fully independent. Schmidt-Eenboom $(2001,146)$ claims that in joint facilities with the US National Security Agency, Germans are treated like "second class citizens" in terms of access to sensitive intelligence.

20. It should also be noted that Japanese fears of entanglement until the early 1970s resulted in a weaker alliance structure than in the case of West Germany and NATO (see Tsuchiyama 1997, 29-69).

21. The CIA was established in September 1947 as the successor to the Office of Strategic Services, an organization that General Douglas MacArthur famously despised and sought to marginalize in Japan. This resentment extended to Willoughby's overly turf-conscious G-2, which resulted in minimal cooperation between the two spy bodies. This petty rivalry manifested itself during the closing stages of the occupation when the CIC refused to hand over its files, forcing the CIA to recruit Nisei former CIC members as a means of accessing this information. There also seemed to be a clash of ideas over appropriate intelligence-gathering methods. The CIA was believed to be critical of the CIC's crude methods, perhaps best exemplified by the latter's involvement in the 1951 kidnapping of the leftist writer Wataru Kaji. 
22. For instance, this network comprised groups that were collectively known as the KATO or, in some cases, KATOH Agency (kikan), which derives from the first letter of the family name of each group's leader. Most seem to agree that Kawabe and Arisue were part of this network but disagree on the remaining groups.

23. Tatsumi was officially purged, which forced him to work discreetly in assisting Yoshida's intelligence plans. At the same time, Tatsumi also cooperated with Willoughby in intelligence matters, which also helped him avoid potential prosecution. Willoughby allegedly asked Tatsumi to keep their intelligence cooperation secret from Yoshida (Yuasa 2010a, 2010c).

24. The United Kingdom and the United States were lukewarm regarding the Singapore proposal. CRC's intelligence operations against China ended up being small scale and primarily focused on operations within Japan (Inoue 2008).

25. The other two elements of Murai's proposal were OSINT and SIGINT.

26. Furuno's plan called for the establishment of a "Voice of Japan," which was clearly modeled on the "Voice of America" (Inoue 2008, 45).

27. As a result of the furor, Murai's proposal was not even publicly announced (Inoue 2008, 46). Masaya Inoue offers a slightly different interpretation of events, arguing that while Ogata wished to establish a JCIA in the future, domestic opposition forced him to announce what was in essence the Furuno proposal, which he claimed was his own. Personal communication with the author, September 3, 2011.

28. Murai was transferred to the Kyoto and then Kyushu prefectural police forces after which he retired to set up Japan's first private security company.

29. As evidence of this claim, Arima $(2010 \mathrm{~b}, 172)$ cites a former Soviet agent named Yuri Rastvorov who revealed the names of foreign agents providing information to the KGB after his defection to the United States in 1954. Higure committed suicide by jumping out of a window during police interrogation.

30. Tetsurō Katō suggests Sono leaked news of Murai's detainment to the Japanese media (cited in Waseda Daigaku Seiji Keizai Kenkyūjo 2009).

31 . Former CIRO director Yoshio Ōmori $(2005,37)$ also suggests interagency disputes led to Murai's downfall.

32. An important exception is an excellent study by Andrew Oros (2008, chap. 5), which examines Japan's surveillance satellite program from the perspective of the security identity of domestic antimilitarism.

33. In an excellent study, Yasuhiro Izumikawa (2010) disaggregates the norm of Japanese antimilitarism into three constituent elements-pacifism, antitraditionalism, and fear of entrapment - to explain Japan's traditional reluctance to deploy its military abroad and its increasing activism over the last decade. The perceived link between a proactive security policy and a retreat from democratic reforms is highlighted in Midford $(2011,51)$.

34. It should also be noted that around the same time the government's Subversive Activities Prevention Bill-legislation upon which the PSIA would be ultimately based-was also forced to undergo amendments due to strong antimilitaristic fears among the public (Kaneko 2011, 303). 
35. In 1967 a Japanese citizen, Bō Uchikawa, was arrested in the Soviet Union for spying. Uchikawa confessed to Soviet interrogators that the CIRO and the Institute for World Economics and Politics had dispatched him. A Japanese government spokesman claimed Uchikawa had resigned from the institute and was therefore a private citizen, thereby absolving Tokyo of any responsibility in the incident. This explanation failed to convince some critics such as the Japan Socialist Party's Kanjū Katō who argued, quite correctly, that if Uchikawa had been able to make it back to Japan safely, his report would surely have found its way to the CIRO (Shūgiin 1967).

36. In a disturbing parallel with the Japan Defense Agency's 1963 "three arrows study," the CIRO was accused of drawing up a list of countermeasures, based on the experiences of 1960, to deal with an anticipated, large-scale citizens' movement opposed to revision of the US-Japan Security Treaty in 1970 (Sangiin 1977).

37. Former influential LDP politician Masaharu Gotōda made this reference (Sangiin 1983). Nakanishi $(2010,139)$ similarly argues that Japan has an anti-intelligence consciousness resulting from its militaristic past.

38. Of course, it should be noted that there was a low risk of this "reverse entrapment" occurring considering what Cha $(2009 / 2010,159)$ highlights as the tight nature of the US alliance with Japan, which helped to limit the likelihood of aggressive Japanese actions, even in the intelligence field.

\section{References}

Allison, Graham. 1971. Essence of Decision: Explaining the Cuban Missile Crisis. New York: Harper Collins.

Anonymous. 1982. "On the Way to Securing a World Position? Japan's Intelligence Agencies and Their Activities." Japan Quarterly 29, 2: 159-162.

Arima, Tetsuo. 2010a. CIA to Sengo Nihon: Hoshu Gōdō, Hoppō Ryōdo, Saigunbi. Tokyo: Heibonsha.

- 2010b. Daihonei Sanbō wa Sengo nani to Tatakattanoka. Tokyo: Shinchōsha.

Berger, Thomas. 1993. "From Sword to Chrysanthemum: Japan's Culture of Anti-militarism." International Security 17, 4: 119-150.

-1998. Cultures of Antimilitarism: National Security in Germany and Japan. Baltimore: Johns Hopkins University Press.

Boyd, J. Patrick, and Richard Samuels. 2005. "Nine Lives? The Politics of Constitutional Reform in Japan." Policy Studies 19. Washington, DC: East-West Center.

Calder, Kent E. 1988. "Japanese Foreign Economic Policy Formation: Explaining the Reactive State." World Politics 40, 4: 517-541.

Cha, Victor. 2009/2010. "Powerplay Origins of the U.S. Alliance System in Asia.” International Security 34, 3: 158-196.

Chong, Yon. 1973. Kyanon Kikan kara no Shōgen. Tokyo: Banchō Shobō, cited in Yuasa, Hiroshi. 2011. "Rekishi ni Kieta Sanbō, Yoshida Shigeru to Tatsumi Eiichi (52): Sōri Daijin no '007' o Tsukure.” MSN.SankeiNyūsu, 
March 6. http://sankei.jp.msn.com/life/print/110306/art11030607430002 -c.htm (accessed May 21, 2011).

Dorling, Philip. 2011. "WikiLeaks Unveils Japanese Spy Agency." Sydney Morning Herald, February 21. www.smh.com.au/technology-news /wikileaks-unveils-japanese-spy-agency-20110220-1b17a.html (accessed April 7, 2011).

Dower, John. 1969. "The Eye of the Beholder: Background Notes on the U.S.-Japan Military Relationship." Bulletin of Concerned Asian Scholars 2, 1: 17 .

-2000. Embracing Defeat: Japan in the Wake of World War II. New York: W. W. Norton.

Finnegan, Michael. 2009. Benchmarking America's Military Alliances: NATO, Japan and the Republic of Korea. Washington, DC: Center for U.S.Korea Policy, Asia Foundation.

Handa, Yūichirō. 1999. Yōkai suru Kōanchōsachō: Habōhō Kaitei no Jittai. Tokyo: Gendai Shokan.

Hansen, James H. 1996. Japanese Intelligence: The Competitive Edge. Washington, DC: NIBC Press.

Haruna, Mikio. 2000. Himitsu no Fairu: CIA to Tai-Nichi Kōsaku (jō). Tokyo: Shinchō Bunko.

Hatakeyama, Seikō. 2007. Nani mo Shiranakatta Nihonjin: Sengo Bōryaku Jiken no Shinsō. Tokyo: Shōdensha.

Inoue, Masaya. 2008. "Yoshida Shigeru no Chūgoku 'Gyakushinkō' Kōsō." Kokusai Seiji 151: 36-53.

Izumikawa, Yasuhiro. 2010. "Explaining Japanese Antimilitarism: Normative and Realist Constraints on Japan's Security Policy." International Security 35, 2: 123-160.

Johnson, Chalmers. 1972. Conspiracy at Matsukawa. Berkeley: University of California, Center for Japanese and Korean Studies.

- 1977. "MITI and Japanese International Economic Policy." In The Foreign Policy of Modern Japan, ed. R. Scalapino, 227-279. Berkeley: University of California Press.

Jourdonnais, Adam. 1963. "Intelligence in the New Japan." Studies in Intelligence 7 , 3. www.cia.gov/library/center-for-the-study-of-intelligence/ kent-csi/vol7no3/html/vo7i3a01p-0001.htm (accessed March 3, 2011).

Kaneko, Masashi. 2011. "Nihon: Sōō no 'Jitsuryoku' o Moteru ka." In Interijensu naki Kokka wa Horobu: Sekai no Jōhō Komyuniti, ed. Nakanishi Terumasa and Ochiai Kōtarō, 300-344. Tokyo: Aki Shobō.

Katzenstein, Peter. 1996. Cultural Norms and National Security: Police and Military in Postwar Japan. Ithaca, NY: Cornell University Press.

Katzenstein, Peter J., and Nobuo Okawara. 1993. "Japan's National Security: Structures, Norms, and Policies." International Security 17, 4: 84-118.

Kitaoka, Hajime. 2005. "Japanese Intelligence System: Past, Now [sic] and Challenges for the Future." Paper presented at Nuffield College, Oxford University, May. 
Kluckhohn, Frank. 1952. "Heidelberg to Madrid: The Story of General Willoughby." Reporter, August 19. www.maebrussell.com/Articles_and Notes/Charles_Willoughby.html, (accessed March 24, 2011).

Koh, Byung Chul. 1989. Japan's Administrative Elite. Berkeley: University of California Press.

Kotani, Ken. 2009. Japanese Intelligence in World War II. Oxford: Osprey Publishing.

Krieger, Wolfgang. 2009. "U.S. Patronage of German Postwar Intelligence." In Handbook of Intelligence Studies, ed. L. Johnson, 91-102. London and New York: Routledge.

Kurita, Naoki. 1996. Ogata Taketora: Jōhō Soshiki no Shusaisha. Tokyo: Yoshikawa Kobunkan.

Kuroi, Buntarō. 2007. Nihon no Jōhō Kikan: Shirarezaru Taigai Interijensu no Zenbō. Tokyo: Kōdansha.

Mainichi Shimbun. 2009. July 26, 1.

Meguro, Katsuo. 1953. "Shinjōhō Kikan to Ogata Kōsō." Tōhō Keizai 24, 1: 26.

Mercado, Stephen. C. 2002. The Shadow Warriors of Nakano: A History of the Imperial Japanese Army's Elite Intelligence School. Dulles, VA: Brassey's, Inc.

Midford, Paul. 2011. Rethinking Japanese Public Opinion and Security: From Pacifism to Realism? Stanford: Stanford University Press.

Mori, Ei. 2008. Kuro no Kikan: Sengo “Tokumu Kikan” wa ika ni Fukkatsu shitaka. Tokyo: Shōdensha.

Murai, Jun. 1952. "Chian Mondai no Kaiko to Tenbō.” Jichi Jihō 5, 10: 2-6.

Nakanishi, Terumasa. 2010. "'Buki naki Sensō' no Rekishi to Shinjitsu." In Bōkoku no Interijensu: "Buki naki Sensō" to Nihon no Mirai, ed. T. Kano, 30-61. Tokyo: Nihon Bungeisha.

Ōmori, Yoshio. 2005. Nihon no Interijensu Kikan. Tokyo: Bungei Shinsho.

Oros, Andrew. 2002. "Japan's Growing Intelligence Capability." International Journal of Intelligence and Counterintelligence 15, 1: 1-25.

2007. "Explaining Japan's Tortured Course to Surveillance Satellites." Review of Policy Research 24, 1: 29-48.

2008. Normalizing Japan: Politics, Identity and the Evolution of Security Practice. Stanford: Stanford University Press.

Pekkanen, Saadia, and Paul Kallender-Umezu. 2010. In Defense of Japan: From the Market to the Military in Space Policy. Stanford: Stanford University Press.

Petersen, Michael. 2006. "The Intelligence That Wasn't: CIA Name Files, the U.S. Army, and Intelligence Gathering in Occupied Japan." In Researching Japanese War Crimes: Introductory Essays, ed. E. Drea et al., 197-230. Washington, DC: National Archives and Records Administration for the Nazi War Crimes and Japanese Imperial Government Records Interagency Working Group.

Samuels, Richard. 2007. Securing Japan: Tokyo's Grand Strategy and the Future of East Asia. Ithaca, NY: Cornell University Press. 
Sangiin Honkaigi Gijiroku dai 8-gō. 1952. http://kokkai.ndl.go.jp, December 3 (accessed May 12, 2011).

Sangiin Hōmu Iinkai Gijiroku dai 10-gō. 1977. http://kokkai.ndl.go.jp, April 1 (accessed May 12, 2011).

Sangiin Naikaku Iinkai Gijiroku dai 10-gō. 1986. http://kokkai.ndl.go.jp, May 21 (accessed May 12, 2011).

Sangiin Naikaku Iinkai Gijiroku dai 4-gō. 1983. http://kokkai.ndl.go.jp, March 23 (accessed May 12, 2011).

Schmidt-Eenboom, Erich. 2001. "The Bundesnachrichtendienst, the Bundeswehr and Sigint in the Cold War and After." Intelligence and $\mathrm{Na}$ tional Security 16, 1: 146.

Shūgiin Hōmu Iinkai Gijiroku dai 28-gō. 1967. http://kokkai.ndl.go.jp, June 30 (accessed May 13, 2011).

Shūgiin Honkaigi Gijiroku dai 6-gō. 1952. http://kokkai.ndl.go.jp, November 26 (accessed May 13, 2011).

Shūgiin Naikaku Iinkai Gijiroku dai 15-gō. 1986. http://kokkai.ndl.go.jp, May 8 (accessed May 13, 2011).

Shūgiin Naikaku Iinkai Gijiroku dai 5-gō. 1958. http://kokkai.ndl.go.jp, February 20 (accessed May 13, 2011).

Taigai Jōhō Kinō Kyōka ni kansuru Kondankai. 2005. Taigai Jōhō Kinō Kyōka ni Mukete, September 13.

Tsuchiyama, Jitsuo. 1997. "Dōmei no Shūen? Nichi-Bei Kankei no Yukue." In Reisengo no Nichi-Bei Kankei, ed. P. Gourevitch, T. Inoguchi, and C. Purrington, 29-69. Tokyo: NTT Shuppan.

Tsukamoto, Katsuichi. 2008. Jieitai no Jōhōsen: Rikumaku Daini Buchō no Kaisō. Tokyo: Soshisha.

Waseda Daigaku Seiji Keizai Kenkyūjo. 2009. "20 Seiki Media Kenkyūjo Tokubetsu Kenkyūkai: CIA to Ogata Taketora." http://members.jcom .home.ne.jp/katote/0907OGATA.pdf, July 25 (accessed May 21, 2011).

Williams, Brad. 2010. "The Challenges of Intelligence Oversight in a Normalising Japan." In Democratic Oversight of Intelligence Services, ed. D. Baldino, 161-186. Sydney: Federation Press.

Yuasa, Hiroshi. 2010a. "Rekishi ni Kieta Sanbō, Yoshida Shigeru to Tatsumi Eiichi (36): Shushō no Gunji Komon o Haimeisu." Sankei Shimbun, November 7, p. 6.

_. 2010b. "Rekishi ni Kieta Sanbō, Yoshida Shigeru to Tatsumi Eiichi (11): Hanamegane to Kaze no Otoko to Kenka Tarō ga ita." Sankei Shimbun, May 16, p. 6.

. 2010c. "Rekishi ni Kieta Sanbō, Yoshida Shigeru to Tatsumi Eiichi (40): Gokuhi Katsudō, Futatsu no Kao o Motsu Otoko." MSN.Sankei Nyūsu, December 5. http://sankei.jp.msn.com/life/news/110113/art11 011321470069-n1.htm (accessed May 23, 2011).

. 2011. "Rekishi ni Kieta Sanbō, Yoshida Shigeru to Tatsumi Eiichi (54): 'Chūō Jōhōkyoku' Kōsō no Zasetsu.” MSN.SankeiNyūsu, March 20. http://sankei.jp.msn.com/life/print/110320/art11032008070001-c.htm (accessed May 23, 2011). 